\title{
Serum C-reactive protein levels predict neurological outcome after aneurysmal subarachnoid hemorrhage
}

\author{
O nível sérico da proteína C-reativa como fator preditivo do prognóstico neurológico após \\ hemorragia subaracnóidea aneurismática
}

Flávio Ramalho Romero', Eduardo de Freitas Bertolini², Eberval G. Figueiredo³, Manoel Jacobsen Teixeira ${ }^{4}$

\begin{abstract}
Objectives: Our aim was to evaluate the relationship between serum C-reactive protein (CRP) levels and the neurological prognosis and development of vasospasm in patients with aneurysmal subarachnoid hemorrhage (aSAH). Methods: Eighty-two adult patients with aSAH diagnoses were prospectively evaluated. Glasgow Coma Scale (GCS) score, Hunt and Hess grade, Fisher grade, cranial CT scans, digital subtraction angiography studies and daily neurological examinations were recorded. Serial serum CRP measurements were obtained daily between admission and the tenth day. Glasgow Outcome Scale (GOS) and the modified Rankin Scale (mRS) were used to assess the prognosis. Results: Serum CRP levels were related to severity of aSAH. Patients with lower GCS scores and higher Hunt and Hess and Fisher grades presented statistically significant higher serum CRP levels. Patients with higher serum CRP levels had a less favorable prognosis. Conclusions: Increased serum CRP levels were strongly associated with worse clinical prognosis in this study.
\end{abstract}

Key words: C-reactive protein, subarachnoid hemorrhage, vasospasm, intracranial aneurysm.

\section{RESUMO}

Objetivos: Nosso propósito foi avaliar a relação entre os níveis séricos de proteína C-reativa (PCR), o prognóstico neurológico e o desenvolvimento de vasoespasmo em pacientes com hemorragia subaracnóidea aneurismática (HSAa). Métodos: Foram avaliados prospectivamente 82 pacientes adultos com diagnóstico de HSAa. Foram anotados em prontuário: a escala de coma de Glasgow (ECG), a escala de Hunt-Hess, a escala de Fisher, TC de crânio, angiografia cerebral e o exame neurológico diário. Foi determinada diariamente a PCR sérica, da admissão ao décimo dia. Foi utilizadas a escala de resultados de Glasgow e a escala de Rankin modificada (mRS) para avaliar o prognóstico. Resultados: Os niveis séricos de PCR estavam relacionados à severidade da HSAa. Pacientes com EGC baixos e altos graus pelas escalas de Hunt-Hess e Fisher tiveram níveis de PCR séricos estatisticamente elevados. Pacientes com altos níveis de PCR séricos tiveram prognóstico menos favorável. Conclusões: Aumentos dos níveis séricos da PCR foram fortemente associados com pior prognóstico clínico neste estudo.

Palavras-Chave: proteína C-reativa, hemorragia subaracnóidea, vasoespasmo, aneurisma intracraniano.

Cerebral vasospasm is the major cause of delayed morbidity and mortality following aneurysmal subarachnoid hemorrhage (aSAH). Despite recent advances in the management of patients with ruptured cerebral aneurysms, case fatality rates remain high (35 to $50 \%)^{1-3}$. More than $40 \%$ of survivors experience long-term cognitive and functional limitations ${ }^{1,3-5}$. Although approximately two-thirds of patients with aneurysmal SAH develop angiographic vasospasm, only half of this group will develop a delayed neurological deficit ${ }^{1,3,6-9}$.

Experimental and clinical evidence suggests that intercellular adhesion molecule-1 (ICAM-1) mediating leukocyte migration may play a crucial role in the pathogenesis of cerebral vasospasm ${ }^{9-13}$. SAH increases endothelial ICAM-1 expression ${ }^{1,3-5,14,15}$ and the resultant perivascular leukocyte migration ${ }^{1,3-5,9,16,17}$. Furthermore, serum ICAM-1 levels correlate with the onset of cerebral vasospasm ${ }^{1,3,6-9}$. Perivascular chemokine-activated inflammatory cells synthesize and release endothelin-1, a potent vasoconstrictor, as well as superoxide free radicals, thus leading to inactivation of nitric oxide (NO) and vasoconstriction ${ }^{1,3,6-9,14,15}$. Anti-ICAM-1 antibodies decrease leukocyte migration and attenuate cerebral vasospasm after $\mathrm{SAH}^{1,3,6-9}$.

\footnotetext{
${ }^{1}$ Neurosurgeon at Hospital Ipiranga, São Paulo SP, Brazil, and Hospital São Luiz, São Paulo SP, Brazil. Postgraduate student in Neurosurgery Division, University of São Paulo, São Paulo SP, Brazil;

${ }^{2}$ Neurosurgeon at Hospital Ipiranga/SUS, São Paulo SP, Brazil;

${ }^{3}$ Head of Neurovascular Group, Neurosurgery Division, Hospital das Clínicas, University of São Paulo Medical School, São Paulo SP, Brazil;

${ }^{4}$ Head of Neurosurgery Division, Hospital das Clínicas, University of São Paulo Medical School, São Paulo SP, Brazil.

Correspondence: Flávio Ramalho Romero; Rua Pascoal Vita 366 / ap. 94; 05445-000 São Paulo SP - Brasil; E-mail:frromero@ig.com.br / romeroncr@gmail.com Conflict of interest: There is no conflict of interest to declare.

Received 21 March 2011; Received in final form 29 August 2011; Accepted 06 September 2011
} 
Identifying risk factors may improve clinical prediction and allow for more effective treatment of vasospasm. Measurement of sensitive inflammatory markers, such as C-reactive protein (CRP), significantly increases the ability to make accurate predictions and prevent or appropriately treat coronary thrombotic events ${ }^{8,18,19}$. Previous clinical studies have shown that elevated levels of high-sensitivity CRP could predict the development of coronary vasospasm ${ }^{8,9}$. Berk et al. ${ }^{8}$ found that elevated CRP was associated with increased risk of a subsequent myocardial infarction. Interest in inflammatory markers for cerebral vasospasm has increased, particularly when related to neurological outcomes.

In this study, we measured serum CRP levels in patients with aSAH and analyzed the relationships between systemic CRP levels and the severity of aSAH.

\section{METHODS}

Between May 2006 and May 2010, 82 adult patients were selected for a prospective cohort study at Hospital Ipiranga/ SUS in São Paulo. The inclusion criteria were as follows: 1) diagnosis of aSAH and cerebral aneurysms established by a CT scan and four-vessel DS angiography study; 2) patient age $>18$ years; 3) patient admission to our institutions within the first 24 hours postictus. The exclusion criteria were concomitant or recent acute myocardial infarction, recent surgery ( $\leq 30$ days) prior to the event, and/or clinical or laboratory evidence of chronic systemic infection. In addition, patients who died before completing 10 days of treatment were not included.

Patient demographics, clinical status on admission Glasgow Coma Scale (GCS) (GCS scores and Hunt and Hess grades), head CT scans, severity of the SAH blood clot load (Fisher grades), location of a ruptured aneurysm (standard four-vessel DS angiography) and neurological examinations on admission and daily thereafter were recorded. Surgical clipping was performed in $56(68.2 \%)$ of the 82 patients for $70(76.1 \%)$ of the 92 aneurysms, whereas endovascular treatment was used in 26 patients (31.7\%) for 22 (23.9\%) of the 92 aneurysms. The selection of surgical versus endovascular treatment was based on criteria, such as the anatomical location of the lesion, the size and morphological features of the aneurysm, the presence of multiple aneurysms, the presence of a mass effect caused by the aneurysm and/or an associated hematoma, and the patient's neurological and general medical condition and preference.

The serum CRP levels were measured daily between admission and the tenth day, and the measurements obtained were recorded. The patients' clinical outcome was evaluated using the Glasgow Outcome Scale (GOS) and modified Rankin Scale (mRS) at discharge from our institutions. This study was approved by the local Ethics Committee. Statistical analyses were performed using SAS version 9.1.3.

\section{RESULTS}

The admission GCS scores ranged from 3 to 15 (mean=12). Hunt and Hess scores on admission ranged from $\mathrm{I}$ to $\mathrm{V}$ (mean=2.5), and Fisher grades from 1 to 4 (mean=1.5). The GOS scores on discharge ranged from 2 to 5 (mean=4.0), and the range of mRS scores was from 0 to 5 (mean=1.3).

A progressive increase in CRP levels from admission to the third day post ictus was observed, followed by a slow decrease until the ninth day (Fig 1). Patients with lower GCS scores presented increased CRP measurements (correlation coefficient methodology; $\mathrm{z}=-8.912, \mathrm{p}<0.0001, \mathrm{r}=-0.89$ ) (Fig 2). Low admission GCS scores were significantly inversely correlated with high serum CRP values. Likewise, patients with higher Hunt and Hess grades on admission developed significantly higher serum CRP levels (correlation coefficient methodology; $\mathrm{z}=6.467, \mathrm{p}<0.0001, \mathrm{r}=0.82$ ). Similarly, patients with higher Fisher grades on admission showed increased levels of CRP (correlation coefficient methodology; $\mathrm{z}=7.652, \mathrm{p}<0.0001, \mathrm{r}=0.86$ )

There was no statistically significant difference in serum CRP levels between the group of patients undergoing surgical clipping and those undergoing endovascular coil occlusion. With regard to their GOS scores, patients with higher serum CRP levels (correlation coefficient methodology; $\mathrm{z}=-6.181, \mathrm{p}<0.0001, \mathrm{r}=-0.81$ ) (Fig 3) presented less favorable outcomes. A statistically significant inverse correlation was

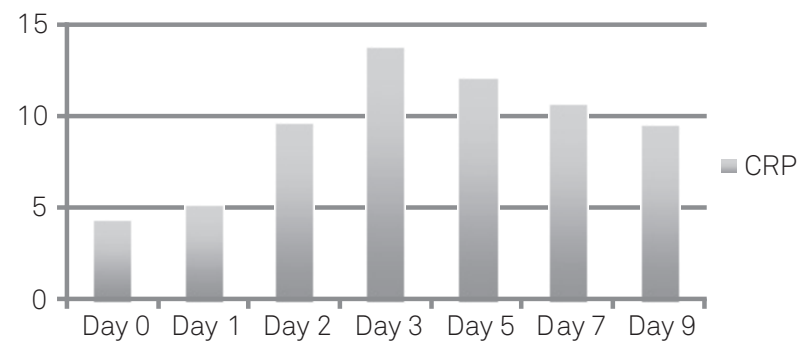

Fig 1. Schematic representation of summated measured serum CRP levels of our patients. CRP: C-reactive protein.

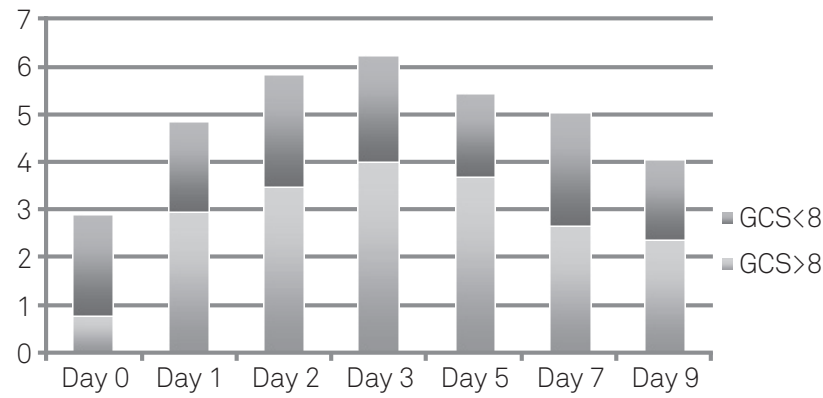

Fig 2. Schematic representation of serum CRP levels with regard to the GCS score at admission. CRP: C-reactive protein; GCS: Glasgow Coma Scale. 


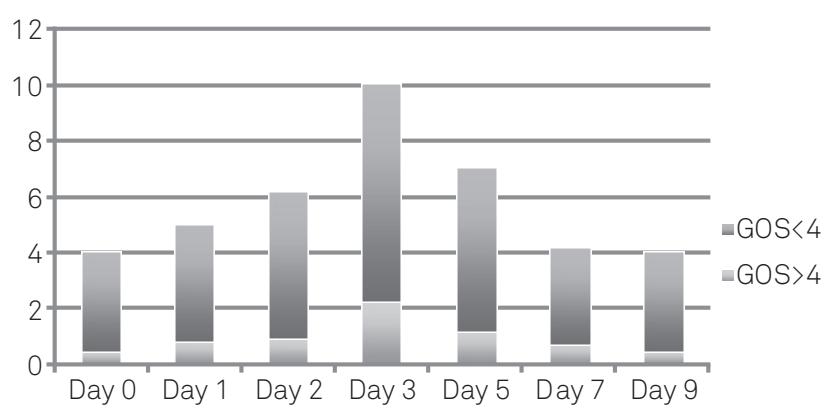

Fig 3. Schematic representation of serum CRP measurements in patients with GOS score $\geq 4$ versus patients with GOS score $<4$ at discharge. CRP: C-reactive protein; GOS: Glasgow Outcome Scale.

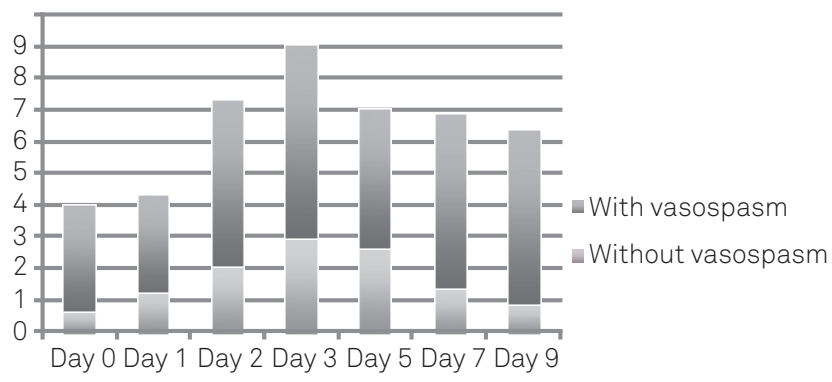

Fig 4. Schematic representation of serum C-reactive protein levels in patients with and without vasospasm.

established in our series between serum CRP levels and GOS scores. A similar statistically strong relationship was found between mRS scores on discharge and CRP measurements (correlation coefficient methodology; $\mathrm{z}=6.762, \mathrm{p}<0.0001$, $\mathrm{r}=0.82$ ). Occurrences of vasospasm were significantly correlated with higher CRP levels (Fig 4).

\section{DISCUSSION}

Delayed cerebral vasospasm is associated with high rates of morbidity and mortality. Several inflammatory mechanisms are directly involved in the pathogenesis of cerebral vasospasm, with increased levels of various soluble adhesion molecules (such as E-selectin, intercellular adhesion molecule- 1 and vascular adhesion molecule-1) and cytokines (such as IL- 6 and IL- 1 ) that have been detected in the plasma and CSF of patients with aSAH ${ }^{3,6-9}$.

CRP is a sensitive inflammatory marker, with synthesis in hepatocytes. It is strongly stimulated by interleukin$6^{1-3,6,6,720-23}$. Additionally, IL-1, which has been implicated in the pathogenesis of cerebral vasospasm, also provides a strong stimulus for CRP synthesis ${ }^{1,3-5}$. Therefore, elevated CRP concentrations may well be associated with an increased possibility of developing cerebral vasospasm and subsequently a delayed ischemic neurological deficit $(\text { DIND) })^{1,3,24-29}$.

There was a strong inverse correlation between admitting GCS scores and serum CRP levels on admission $(\mathrm{r}=-0.89$ and $\mathrm{r}=-0.82$, respectively). Hunt and Hess and Fisher grades were also correlated in a statistically significant fashion with the CRP measurements in our cohort. These data clearly indicate that CRP levels significantly correlate with the severity of aSAH and with occurrences of vasospasm. Furthermore, the elevated CRP levels were associated with worse clinical outcome, as expressed in GOS and mRS scores. Additionally, we found no statistically significant differences in occurrences of angiographic vasospasm between patients undergoing surgical treatment and those undergoing endovascular coil occlusion.

Our strict inclusion criteria minimized the influence of other confounding factors, such as systemic infection or concomitant systemic conditions, and hence the statistical analysis defining the influence of CRP levels on vasospasm occurrences and neurological final outcomes is compelling. Unfortunately, the clinical significance of elevated serum CRP measurements in patients with aSAH is confounded by the fact that most of these patients may have other concomitant systemic infections or pathological conditions that could potentially result in increased serum CRP concentrations. Additionally, the surgical manipulation in these patients could influence the systemic CRP levels.

It is well known that the clinical outcome among patients with aSAH depends on many factors. The systemic association between CRP levels and clinical outcomes may well be influenced by other parameters in a complex and frequently unpredictable way. In addition, CRP is a sensitive but nonspecific inflammatory marker. A largescale, multicenter, prospective clinical study is necessary to validate our results and to determine the role of serum CRP in identifying patients who are at high risk of developing cerebral vasospasm.

In conclusion, this prospective clinical study demonstrated that the clinical and radiologic severity of aSAH correlated significantly with serum CRP levels, since patients with low GCS scores and high Hunt and Hess and Fisher grades presented elevated serum CRP levels. Additionally, CRP levels were able to predict occurrences of vasospasm and poor clinical outcomes in a statistically significant fashion. Routine use of CRP levels may identify patients who are at high risk of developing cerebral vasospasm and may have a positive impact on therapeutic strategies and the future management of patients with aSAH. 


\section{References}

1. Bengzon J, Grubb A, Bune A, Heillström K, Lindström V, Brandt L. C-reactive protein levels following standard neurosurgical procedures. Acta Neurochir (Wien) 2003;145:667-671.

2. McGirt MJ, Garces Ambrossi GL, Huang J, Tamargo RJ. Simvastatin for the prevention of symptomatic cerebral vasospasm following aneurysmal subarachnoid hemorrhage: a single-institution prospective cohort study. Neurosurgery 2009; 110:968-974.

3. Fountas KN, Tasiou A, Kapsalaki EZ, et al. Serum and cerebrospinal fluid C-reactive protein levels as predictors of vasospasm in aneurysmal subarachnoid hemorrhage. Clinical article. Neurosurg Focus 2009;26:22-31.

4. Kramer AH, Gurka MJ, Nathan B, Dumont AS, Kassell NF, Bleck TP. Statin use was not associated with less vasospasm or improved outcome after subarachnoid hemorrhage. Neurosurgery 2008; $62: 422-430$

5. Suzuki R, Masaoka H, Hirata Y, Marumo F, Isotani E, Hirakawa K. The role of endothelin-1 in the origin of cerebral vasospasm in patients with aneurysmal subarachnoid hemorrhage. J Neurosurg 1992;77:96-100.

6. Vajkoczy P, Meyer B, Weidauer S, et al. Clazosentan (AXV-034343), a selective endothelin $A$ receptor antagonist, in the prevention of cerebral vasospasm following severe aneurysmal subarachnoid hemorrhage: results of a randomized, double-blind, placebocontrolled, multicenter Phase lla study. J Neurosurg 2005;103:9-17.

7. Goddard AJ, Raju PP, Gholkar A. Does the method of treatment of acutely ruptured intracranial aneurysms influence the incidence and duration of cerebral vasospasm and clinical outcome? J Neurol Neurosurg Psychiatry 2004;75:868-872.

8. Berk BC, Weintraub WS, Alexander RW. Elevation of C- reactive protein in "active" coronary artery disease. Am J Cardiol 1990;65:168-172.

9. Carr WP. The role of the laboratory in rheumatology. Acute-phase proteins. Clin Rheum Dis 1983;9:227-239.

10. Dumont AS, Dumont RJ, Chow MM, et al. Cerebral vasospasm after subarachnoid hemorrhage: putative role of inflammation. Neurosurgery 2003;53:123-135.

11. Hansen-Schwartz J. Cerebral vasospasm: a consideration of the various cellular mechanisms involved in the pathophysiology. Neurocrit Care 2004;1:235-246.

12. Hergenroeder G, Redell JB, Moore AN, et al. Identification of serum biomarkers in brain-injured adults: potential for predicting elevated intra- cranial pressure. J Neurotrauma 2008;25:79-93.

13. Hoshi T, Shimizu T, Kito K, et al. Immunological study of late cerebral vasospasminsubarachnoid hemorrhage. Detection ofimmunoglobulins, C3, and fibrinogen in cerebral arterial walls by immunofluorescence method. Neuro Med Chir (Tokyo) 1984;24:647-654.

14. Mayberg MR, Batjer HH, Dacey RG Jr, et al. Guidelines for the management of aneurysmal subarachnoid hemorrhage. A statement for healthcare professionals from a special writing group of the Stroke
Council, American Heart Association. Stroke 1994;25:2315-2328.

15. Kasuya $H$, Weir BK, Nakane $M$, et al. Nitric oxide synthase and guanylate cyclase levels in canine basilar artery after subarachnoid hemorrhage. J Neurosurg 1995;82:250-255.

16. Rothoerl RD, Schebesch KM, Kubitza M, Woertgen C, Brawansk A, Pina AL. ICAM-1 and VCAM-1 expression following aneurysmal subarachnoid hemorrhage and their possible role in the pathophysiology of subsequent ischemic deficits. Cerebrovasc Dis 2006;22:143-149

17. Rankin J. Cerebral vascular accidents in patients over the age of 60 . II Prognosis. Scott Med J 1957;2:200-215.

18. Bonita R, Beaglehole R. Modification of Rankin Scale: recovery of motor function after stroke. Stroke 1988;19:1497-1500.

19. van Swieten JC, Koudstaal PJ, Visser MC, Schouten HJ, van Gijn J. Interobserver agreement for the assessment of handicap in stroke patient. Stroke 1988;19:604-607.

20. Lynch JR, Blessing R, White WD, Grocott HP, Newman MF, Laskowitz DT. Novel diagnostic test for acute stroke. Stroke 2004;35:57-63.

21. Suzuki $H$, Kanamaru K, Tsunoda $H$, et al. Heme oxygenase-1 gene induction as an intrinsic regulation against delayed cerebral vasospasm in rats. J Clin Invest 1999;104:59-66.

22. Pluta RM. Delayed cerebral vasospasm and nitric oxide: review, new hypothesis, and proposed treatment. Pharmacol Ther 2005;105:23-56.

23. Mazlam MZ, Hodgson HJ. Interrelations between interleukin-6, interleukin-1 beta, plasma C-reactive protein values, and in vitro C-reactive protein generation in patients with inflammatory bowel disease. Gut 1994;35:77-83.

24. Kassell NF, Sasaki T, Colohan ART, Nazar G. Cerebral vasospasm following aneurysmal subarachnoid hemorrhage. Stroke 1985;16:562-572.

25. Kasuya $H$, Weir BK, Nakane M, et al. Nitric oxide synthase and guanylate cyclase levels in canine basilar artery after subarachnoid hemorrhage. J Neurosurg 1995;82:250-255.

26. Hung MJ, Cherng WJ, Yang NI, Cheng CW, Li LF. Relation of highsensitivity $\mathrm{C}$-reactive protein level with coronary vasospastic angina pectoris in patients without hemodynamically significant coronary artery disease. Am J Cardiol 2005;96:1484-1490.

27. Deshmukh VR, Kakarla UK, Figueiredo EG, Zabramski JM, Spetzler RF. Long-term clinical and angiographic follow-up of unclippable wrapped intracranial aneurysms. Neurosurgery 2006;58:434-442.

28. Cecon AD, Figueiredo EG, Bor-Seng-Shu E, Scaff M, Teixeira MJ. Extremely delayed cerebral vasospasm after subarachnoid hemorrhage. Arq Neuropsiquiatr 2008;66:554-556.

29. Foroni LH, Figueiredo EG, Teixeira MJ, Caldas JG, Leszczynski A, Rivau FR. Saccular aneurysms at middle basilar trunk fenestration. Arq Neuropsiquiatr 2010;68:309-311. 